\title{
Study of estimation of serum LDH and uric acid in preeclampsia and it's clinical correlation
}

\section{Geetha Shivamurthy, Nandini Smanjunath*}

Department of Obstetrics and Gynaecology, Bangalore Medical College and Research Institute, Bangalore, Karnataka, India

Received: 24 September 2020

Revised: 09 November 2020

Accepted: 10 November 2020

\section{*Correspondence:}

Dr, Geetha Shivamurthy,

E-mail: nandinismanjunath225@gmail.com

Copyright: (C) the author(s), publisher and licensee Medip Academy. This is an open-access article distributed under the terms of the Creative Commons Attribution Non-Commercial License, which permits unrestricted non-commercial use, distribution, and reproduction in any medium, provided the original work is properly cited.

\section{ABSTRACT}

Background: Preeclampsia occurs in $2-8 \%$ of pregnancies and a leading cause of maternal and perinatal mortality and morbidity. The objective of this study was to compare serum lactate dehydrogenase (LDH) and uric acid levels in normotensive pregnant women and in women with preeclampsia and to correlate the maternal and perinatal outcomes and severity of the disease with serum LDH and uric acid levels

Methods: A prospective case control study conducted during the period of 18 months involving 100 normotensive pregnant women and an equal no. of patients with preeclampsia admitted under OBG department, Vani Vilas Hospital and Bowring and Lady Curzon hospital, which are affiliated to BMCRI, Bangalore. They were followed up till delivery and early post-partum period. Serum LDH and uric acid levels were sent and maternal and foetal outcomes studied.

Results: There was statistically significant increase in levels of serum LDH and uric acid among cases compared to control group. Higher levels were also associated with significant maternal and foetal complications.

Conclusions: We conclude from this study that the serum LDH and Uric acid are the inexpensive and reliable markers to predict severity and maternal and foetal outcomes in patients with preeclampsia.

Keywords: Preeclampsia, Serum LDH, Uric acid

\section{INTRODUCTION}

Preeclampsia is a clinical syndrome characterised by hypertension and proteinuria. Preeclampsia occurs in 2$8 \%$ of pregnancies and a leading cause of maternal and perinatal mortality and morbidity. ${ }^{1}$ The incidence is still higher in India of around 8-10\%. ${ }^{2}$ As per the world health report the maternal mortality during pregnancy and puerperium is around $12 \%$. In developing countries, $17 \%$ of direct obstetric deaths are as a result of hyprtension. ${ }^{3}$ The disorder is probably multifactorial, although most cases of preeclampsia are characterised by maternal uterine vascular remodelling by placental trophoblast cells. The most common models of the different reports available on animal models that have been used to study different aspects of preeclampsia are placental oxygen dysregulation, abnormal trophoblast invasion, inappropriate maternal vascular damage and maternal and foetal immune interactions. ${ }^{4}$

Lactate dehydrogenise (LDH) is mainly an intracellular enzyme. It is responsible for inter conversion of pyruvate and lactate in the cells. Its levels are several times greater inside the cells than in the plasma. So its levels are increased in the scenario of increased cell leakiness, hemolysis and cell death. Preeclampsia is a multisystem disorder and leads to a lot of cellular death. So, serum LDH levels can be used to assess the extent of cellular death and thereby the severity of disease. ${ }^{5}$ Hence Serum LDH Levels can be further used as help in making decision, regarding the management strategies to improve the maternal and foetal outcome. 
Uric acid (UA) is an end product of purine metabolism. It is filtrated through the glomeruli and almost completely reabsorbed in the proximal convoluted tubules (PCT) by both active and passive carrier mediated processes. It is also actively secreted into the tubules. $85 \%$ of total excreted UA is derived by tubular secretion. Hyperuricemia is found to be one of the earliest laboratory manifestations of preeclampsia.

It is likely to be resulted from reduced UA clearance from reduced glomerular filtration rate (GFR) and reduced tubular secretion. Its increased levels suggest serious impending damage to kidney functions. ${ }^{6}$

\section{Aims and objectives}

Aim and Objective were to compare serum LDH and uric acid levels in normal pregnant women and in women with preeclampsia and to correlate the maternal and perinatal outcomes and severity of the disease with serum LDH and uric acid levels.

\section{METHODS}

\section{Study design}

Comparative case control study.

\section{Study period}

November 2016 to May 2018.

\section{Place of study}

Vani Vilas Hospital and Bowring and Lady Curzon Hospital which are affiliated to BMCRI, Bangalore.

\section{Sample size}

100 from each group selected using random table sampling.

\section{Inclusion criteria}

All pregnant women $\geq 20$ weeks of gestation were enrolled in this study and divided into following groups: healthy normotensive pregnant women- controls, patients of preeclampsia and eclampsia- cases. Cases are divided into two groups: non-severe preeclampsia and severe preeclampsia.?

\section{Exclusion criteria}

These included pregnant women with: essential hypertension or hypertension $<20$ weeks gestation, preexisting diabetes mellitus, renal disease, liver disorder, thyroid disorder, alcoholic, epilepsy and urinary tract infection

\section{Methodology}

After obtaining approval from Institutional Ethical Committee and informed written consent, patients who satisfy inclusion and exclusion criteria were examined and plain blood samples were collected for estimation of serum LDH and UA levels using fully automated biochemical analyser. They were followed up till early postpartum period and babies till early neonatal period for maternal and foetal outcome.

\section{Data analysis}

Data was entered into Microsoft excel data sheet and was analyzed using Statistical package for social sciences (SPSS) 22 version software. Categorical data was represented in the form of frequencies and proportions. Chi-square test or Fischer's exact test (for $2 \times 2$ tables only) was used as test of significance for qualitative data. Continuous data was represented as mean and standard deviation. Independent t test or Mann Whitney U test was used as test of significance to identify the mean difference between two quantitative variables and qualitative variables respectively. $\mathrm{P}$ value less than 0.05 was considered statistically significant.

\section{RESULTS}

Mean LDH among cases was $533.19 \pm 707.79$ (340) and among controls was $240.59 \pm 55.52$ (226). Mean UA among cases and controls was $6.01 \pm 1.69$ (5.8) and 3.88 \pm 0.81 (3.9) respectively. There was significant difference in incidence of eclampsia, HELLP syndrome and abruption between two groups.

Table 1: Comparison of LDH between two groups.

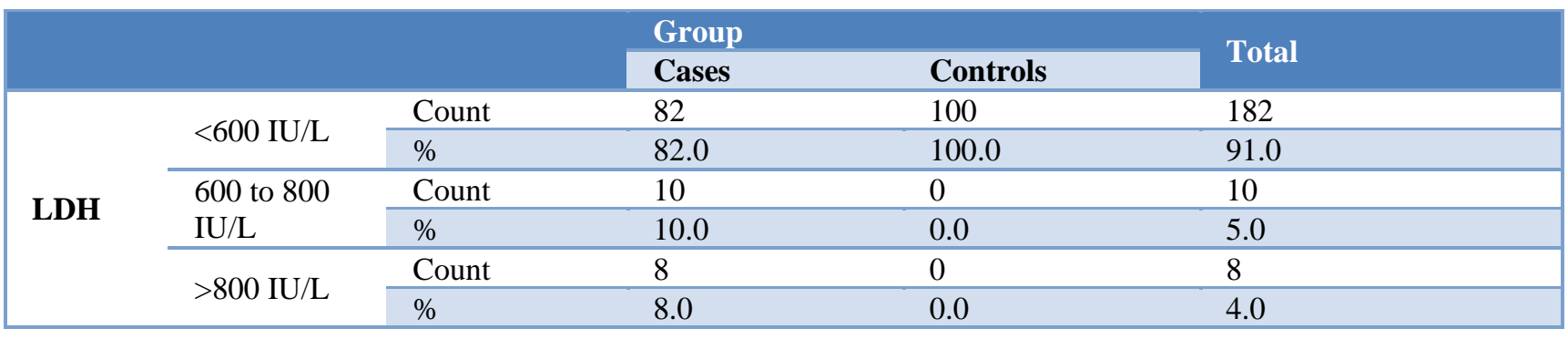




\begin{tabular}{|lllll|} 
& & Group & Total \\
\hline \multirow{2}{*}{ Total } & Cases & Controls & 200 \\
\hline \multirow{2}{*}{ Mean \pm SD (Median) } & $\%$ & 100 & 100 & 100.0 \\
\cline { 2 - 5 } & & 100.0 & 100.0 & $\mathrm{p}<0.001 *$ \\
\hline
\end{tabular}

$\chi 2=19.78, \mathrm{df}=2, \mathrm{p}<0.001 *$. Mean LDH among cases was 533.19 \pm 707.79 (340) and among controls was 240.59 \pm 55.52 (226).

Table 2: Comparison of Uric acid between two groups.

\begin{tabular}{|c|c|c|c|c|c|}
\hline & & & \multicolumn{2}{|l|}{ Group } & \multirow{2}{*}{ Total } \\
\hline & & & Cases & Controls & \\
\hline \multirow{4}{*}{ Uric acid } & \multirow{2}{*}{$<6$} & Count & 54 & 100 & 154 \\
\hline & & $\%$ & 54.0 & 100.0 & 77.0 \\
\hline & \multirow{2}{*}{$>6$} & Count & 46 & 0 & 46 \\
\hline & & $\%$ & 46.0 & 0.0 & 23.0 \\
\hline \multirow{2}{*}{\multicolumn{2}{|c|}{ Total }} & Count & 100 & 100 & 200 \\
\hline & & $\%$ & 100.0 & 100.0 & 100.0 \\
\hline \multicolumn{3}{|c|}{ Mean \pm SD $($ Median $)$} & $6.01 \pm 1.69(5.8)$ & $3.88 \pm 0.81(3.9)$ & $\mathrm{p}<0.001 *$ \\
\hline
\end{tabular}

$\chi 2=59.74, \mathrm{df}=1, \mathrm{p}<0.001 *$. Mean UA among cases and controls was $6.01 \pm 1.69$ (5.8) and 3.88 \pm 0.81 (3.9) respectively.

Table 3: Comparison of perinatal morbidity between two groups.

\begin{tabular}{|c|c|c|c|c|c|c|}
\hline & & \multicolumn{4}{|l|}{ Group } & \multirow{3}{*}{ p value } \\
\hline & & \multicolumn{2}{|l|}{ Cases } & \multicolumn{2}{|c|}{ Controls } & \\
\hline & & Count & $\%$ & Count & $\%$ & \\
\hline \multirow{2}{*}{ LBW } & No & 66 & 66.0 & 87 & 87.0 & \multirow{2}{*}{$<0.001 *$} \\
\hline & Yes & 34 & 34.0 & 13 & 13.0 & \\
\hline \multirow{2}{*}{ IUGR } & No & 71 & 71.0 & 98 & 98.0 & \multirow{2}{*}{$<0.001 *$} \\
\hline & Yes & 29 & 29.0 & 2 & 2.0 & \\
\hline \multirow{2}{*}{ RD } & No & 89 & 89.0 & 96 & 96.0 & \multirow{2}{*}{0.06} \\
\hline & Yes & 11 & 11.0 & 4 & 4.0 & \\
\hline \multirow{2}{*}{ Preterm } & No & 82 & 82.0 & 95 & 95.0 & \multirow{2}{*}{$0.004 *$} \\
\hline & Yes & 18 & 18.0 & 5 & 5.0 & \\
\hline \multirow{2}{*}{ Sepsis } & No & 92 & 92.0 & 96 & 96.0 & \multirow{2}{*}{0.234} \\
\hline & Yes & 8 & 8.0 & 4 & 4.0 & \\
\hline \multirow{2}{*}{$\begin{array}{l}\text { NICU } \\
\text { Admission }\end{array}$} & No & 81 & 81.0 & 91 & 91.0 & \multirow{2}{*}{$0.042 *$} \\
\hline & Yes & 19 & 19.0 & 9 & 9.0 & \\
\hline
\end{tabular}

Table 4: Maternal morbidity comparison between two groups.

\begin{tabular}{|c|c|c|c|c|c|c|}
\hline & & \multicolumn{4}{|l|}{ Group } & \multirow{3}{*}{ p value } \\
\hline & & \multicolumn{2}{|l|}{ Cases } & \multicolumn{2}{|c|}{ Controls } & \\
\hline & & Count & $\%$ & Count & $\%$ & \\
\hline \multirow{2}{*}{ Eclampsia } & No & 92 & 92.0 & 100 & 100.0 & \multirow{2}{*}{$0.004 *$} \\
\hline & Yes & 8 & 8.0 & 0 & 0.0 & \\
\hline \multirow{2}{*}{ HELLP } & No & 94 & 94.0 & 100 & 100.0 & \multirow{2}{*}{$0.013 *$} \\
\hline & Yes & 6 & 6.0 & 0 & 0.0 & \\
\hline \multirow{2}{*}{$\begin{array}{l}\text { CNS } \\
\text { Involvement }\end{array}$} & No & 98 & 98.0 & 100 & 100.0 & \multirow{2}{*}{0.155} \\
\hline & Yes & 2 & 2.0 & 0 & 0.0 & \\
\hline \multirow{2}{*}{ Febrile Illness } & No & 96 & 96.0 & 99 & 99.0 & \multirow{2}{*}{0.174} \\
\hline & Yes & 4 & 4.0 & 1 & 1.0 & \\
\hline \multirow{2}{*}{ PРH } & No & 97 & 97.0 & 99 & 99.0 & \multirow{2}{*}{0.312} \\
\hline & Yes & 3 & 3.0 & 1 & 1.0 & \\
\hline \multirow{2}{*}{ Abruption } & No & 95 & 95.0 & 100 & 100.0 & \multirow{2}{*}{$0.024 *$} \\
\hline & Yes & 5 & 5.0 & 0 & 0.0 & \\
\hline
\end{tabular}

There was significant difference in incidence of eclampsia, HELLP syndrome and abruption between two groups. 
Table 5: LDH and Uric acid levels comparison between NSPE and SPE.

\begin{tabular}{|c|c|c|c|c|c|c|}
\hline \multicolumn{7}{|c|}{ Group statistics } \\
\hline & Group & $\mathbf{N}$ & Mean & SD & Median & $P$ value \\
\hline \multirow{2}{*}{ LDH } & NSPE & 50 & 316.70 & 153.86 & 261.00 & \multirow{2}{*}{$0.002 * \#$} \\
\hline & SPE & 50 & 749.36 & 954.36 & 437.50 & \\
\hline \multirow{2}{*}{ Uric acid } & NSPE & 50 & 5.248 & 1.493 & 4.80 & \multirow{2}{*}{$<0.001 *$} \\
\hline & SPE & 50 & 6.810 & 1.609 & 6.75 & \\
\hline
\end{tabular}

Table 6: Association between LDH and perinatal morbidity and mortality among cases.

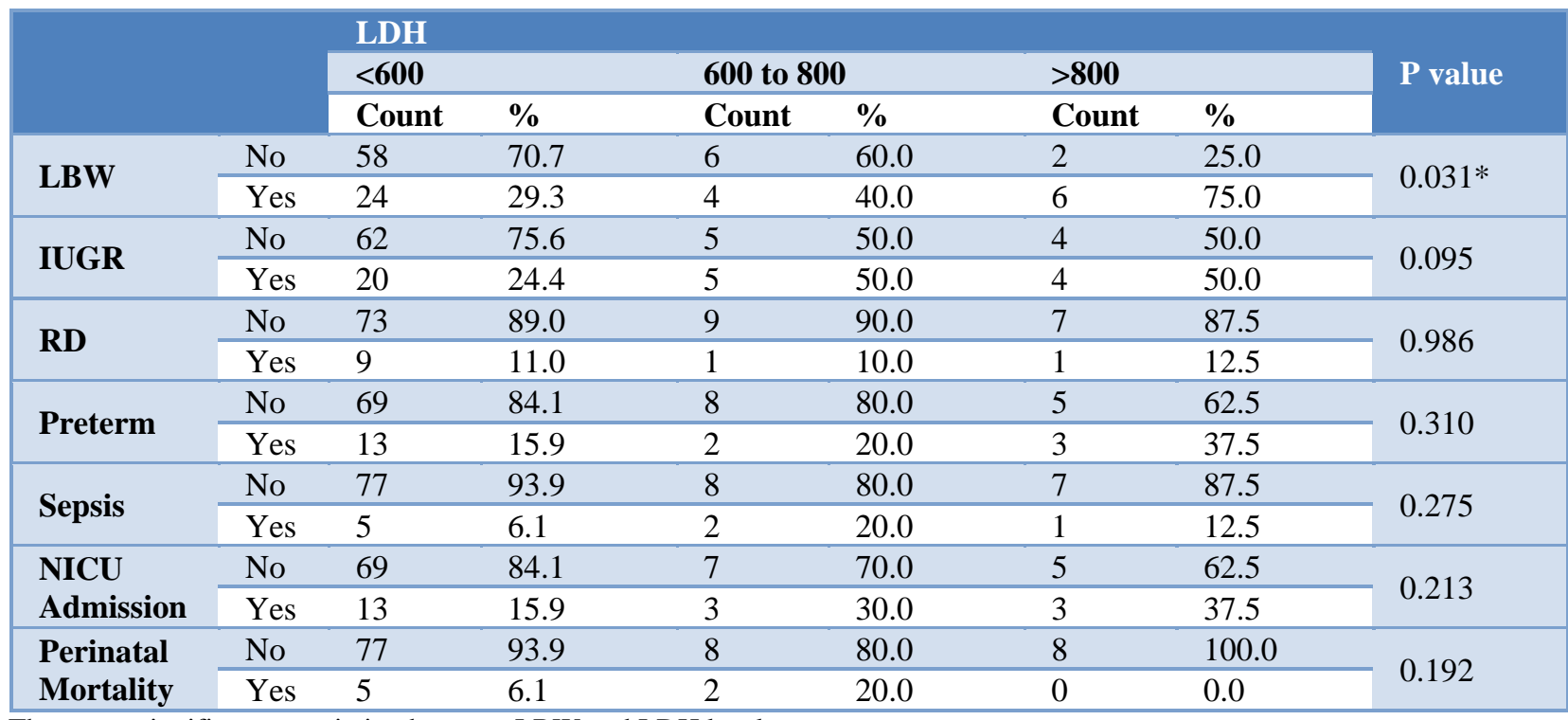

There was significant association between LBW and LDH levels.

Table 7: Association between uric acid and perinatal morbidity and mortality among cases.

\begin{tabular}{|c|c|c|c|c|c|c|}
\hline & & \multicolumn{4}{|c|}{ Uric acid } & \multirow{3}{*}{$P$ value } \\
\hline & & \multicolumn{2}{|l|}{$<6$} & \multicolumn{2}{|l|}{$>6$} & \\
\hline & & Count & $\%$ & Count & $\%$ & \\
\hline \multirow{2}{*}{ LBW } & No & 42 & 77.8 & 24 & 52.2 & \multirow{2}{*}{$0.007^{*}$} \\
\hline & Yes & 12 & 22.2 & 22 & 47.8 & \\
\hline \multirow{2}{*}{ IUGR } & No & 42 & 77.8 & 29 & 63.0 & \multirow{2}{*}{0.106} \\
\hline & Yes & 12 & 22.2 & 17 & 37.0 & \\
\hline \multirow{2}{*}{ RD } & No & 49 & 90.7 & 40 & 87.0 & \multirow{2}{*}{0.547} \\
\hline & Yes & 5 & 9.3 & 6 & 13.0 & \\
\hline \multirow{2}{*}{ Preterm } & No & 49 & 90.7 & 33 & 71.7 & \multirow{2}{*}{$0.014 *$} \\
\hline & Yes & 5 & 9.3 & 13 & 28.3 & \\
\hline \multirow{2}{*}{ Sepsis } & No & 50 & 92.6 & 42 & 91.3 & \multirow{2}{*}{0.813} \\
\hline & Yes & 4 & 7.4 & 4 & 8.7 & \\
\hline \multirow{2}{*}{$\begin{array}{l}\text { NICU } \\
\text { Admission }\end{array}$} & No & 46 & 85.2 & 35 & 76.1 & \multirow{2}{*}{0.248} \\
\hline & Yes & 8 & 14.8 & 11 & 23.9 & \\
\hline \multirow{2}{*}{$\begin{array}{l}\text { Perinatal } \\
\text { Mortality }\end{array}$} & No & 52 & 96.3 & 41 & 89.1 & \multirow{2}{*}{0.162} \\
\hline & Yes & 2 & 3.7 & 5 & 10.9 & \\
\hline
\end{tabular}

There was significant association between uric acid levels with LBW and preterm. 
Table 8: Association between LDH and maternal morbidity among cases.

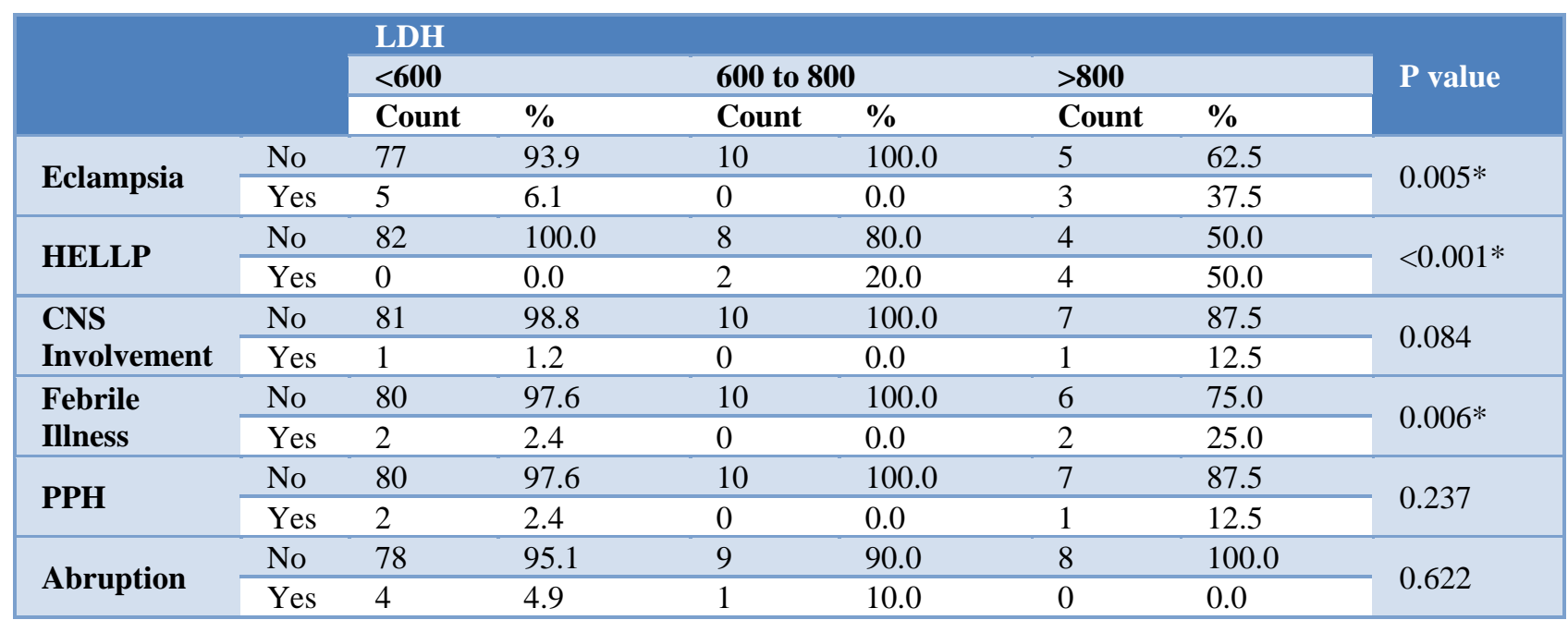

There was significant association between eclampsia, HELLP syndrome and LDH levels.

Table 9: Association between uric acid and maternal morbidity among cases.

\begin{tabular}{|c|c|c|c|c|c|c|}
\hline & & \multicolumn{4}{|c|}{ Uric acid } & \multirow{3}{*}{$P$ value } \\
\hline & & \multicolumn{2}{|l|}{$<6$} & \multicolumn{2}{|l|}{$>6$} & \\
\hline & & Count & $\%$ & Count & $\%$ & \\
\hline \multirow{2}{*}{ Eclampsia } & No & 53 & 98.1 & 39 & 84.8 & \multirow{2}{*}{$0.014 *$} \\
\hline & Yes & 1 & 1.9 & 7 & 15.2 & \\
\hline \multirow[b]{2}{*}{ HELLP } & No & 53 & 98.1 & 41 & 89.1 & \multirow{2}{*}{0.058} \\
\hline & Yes & 1 & 1.9 & 5 & 10.9 & \\
\hline \multirow{2}{*}{$\begin{array}{l}\text { CNS } \\
\text { Involvement }\end{array}$} & No & 54 & 100.0 & 44 & 95.7 & \multirow{2}{*}{0.122} \\
\hline & Yes & 0 & 0.0 & 2 & 4.3 & \\
\hline \multirow{2}{*}{ Febrile Illness } & No & 52 & 96.3 & 44 & 95.7 & \multirow{2}{*}{0.870} \\
\hline & Yes & 2 & 3.7 & 2 & 4.3 & \\
\hline \multirow{2}{*}{ PPH } & No & 54 & 100.0 & 43 & 93.5 & \multirow{2}{*}{0.057} \\
\hline & Yes & 0 & 0.0 & 3 & 6.5 & \\
\hline \multirow{2}{*}{ Abruption } & No & 54 & 100.0 & 41 & 89.1 & \multirow{2}{*}{$0.013^{*}$} \\
\hline & Yes & 0 & 0.0 & 5 & 10.9 & \\
\hline
\end{tabular}

There was significant association between uric acid and eclampsia and abruption.

Mean LDH among NSPE group was $316.70 \pm 153.86$ and median LDH was 261.00 and in SPE group, mean LDH was $749.36 \pm 954.36$ and median LDH was 437.50 . There was significant difference in median LDH levels between NSPE and SPE groups. Mean UA in NSPE group was $5.248 \pm 1.493 \mathrm{mg} / \mathrm{dl}$ and in SPE group was $6.810 \pm 1.609$ $\mathrm{mg} / \mathrm{dl}$. There was significant difference in mean UA levels between two groups.

\section{DISCUSSION}

Hypertensive disorders of pregnancy which frequently manifest as preeclampsia continues to exert an enormous toll in developing countries like India and also in western society. Despite progress in its prevention, detection and treatment, it continues to be the leading cause of maternal death. Research over last decade proved the role of oxidative stress and inflammation in pathophysiology of preeclampsia. Oxidative stress, xanthine oxidase activity and inflammation are important contributors. Various traditional and newer biomarkers were suggested for diagnosis and prognosis of preeclampsia.

In view of this, the present study has been taken up to assess clinical utility of some of the promising biochemical markers like serum LDH and uric acid.

In the present study, the mean maternal age among cases was $23.54 \pm 3.23$ years and among controls was $23.33 \pm 3.16$ years which is comparable to Umasatyasri et al study, $24.5 \pm 3.46$ and $23.46 \pm 3.29$ years among cases and controls respectively. ${ }^{8}$

The mean gestational age in the present study $37.8 \pm 1.8$ weeks among cases is comparable to Umasatyasri et al study (37.6 \pm 2.76 weeks and $36.7 \pm 2.96$ weeks among those with LDH less than 600 and between 600-800). ${ }^{8}$ 
Most of the patients in the present study were primipara (67\% among cases and 64\% among controls) which is comparable to Yadav et al (54\% and $48 \%$ respectively). ${ }^{9}$

Mean systolic blood pressure (BP) among cases and controls was $155.98 \pm 13.32 \mathrm{mmhg}$ and $117.94 \pm 9.87 \mathrm{mmhg}$ respectively which is comparable to Sonagra et al study, $157 \pm 8.77 \mathrm{mmhg}$ and $113 \pm 5.34 \mathrm{mmhg}$ respectively among cases and controls. ${ }^{10}$

Mean diastolic BP among cases and controls was $103.46 \pm 2.05 \mathrm{mmhg}$ and $74.52 \pm 5.19 \mathrm{mmhg}$ respectively which is comparable to Gandhi et al $(96.24 \pm 6.65 \mathrm{mmhg}$ and $70.13 \pm 5.21 \mathrm{mmhg}$ respectively). ${ }^{11}$

Mean serum LDH levels among cases and controls was $533.19 \pm 707 \mathrm{IU} / \mathrm{L}$ and $240.59 \pm 55.5 \mathrm{IU} / \mathrm{L}$ respectively which is comparable to Umasatyasri et al study which showed serum LDH levels of 646.95 \pm 401.64 IU/L among severe preeclampsia group, 400.45 \pm 145.21 among mild preeclampsia group and $278.3 \pm 119.2$ IU/L among normotensives. ${ }^{8}$ Mean serum LDH levels among severe preeclampsia group was higher compared to non-severe preeclampsia indicating that there was significant rise in the LDH levels with increasing severity of the disease. Also comparable to Qublan et al study. ${ }^{12}$ They concluded that serum LDH can be a useful marker for the prediction of adverse outcomes of pregnancy in severe preeclampsia.

In the present study there was significant association between LBW and LDH levels. Among those with LDH $<600,29.3 \%$ had LBW, those with LDH 600 to 800, 40\% had LBW and those with LDH with $>800,75 \%$ had LBW. With increase in LDH levels there was increase in incidence of LBW among cases.

In the present study, there was significant association between eclampsia, HELLP syndrome and LDH levels. Those with $\mathrm{LDH}<600,6.1 \%$ had eclampsia. Those with LDH levels 600 to $800,20 \%$ had HELLP. Those with LDH $>800,37.5 \%$ had eclampsia and 50\% had HELLP.

Mean uric acid levels among cases and controls was $6.01 \pm 1.69 \mathrm{mg} / \mathrm{dl}$ and $3.88 \pm 0.81 \mathrm{mg} / \mathrm{dl}$ in the present study which is statistically significant and comparable to Gandhi et al study of $5.94 \mathrm{mg} / \mathrm{dl}$ and $4.63 \mathrm{mg} / \mathrm{dl}$ respectively. ${ }^{11}$

In the present study, there was significant association between uric acid and eclampsia and abruption. Those with uric acid levels $<6,1.9 \%$ had eclampsia and none had abruption and those with $\mathrm{UA}>6,15.2 \%$ had eclampsia and $10.9 \%$ had abruption. This indicates that the levels of uric acid can be used as a marker for prediction of maternal complication and for prevention of these complications by early intervention.

In the present study, there was significant association between UA levels with LBW and preterm i.e. among those with uric acid levels $<6,22.2 \%$ had LBW, $9.3 \%$ had preterm. Among those with uric acid levels $>6,47.8 \%$ had LBW and $28.3 \%$ had preterm.

Limitation of this study is that the sample size is not large enough to make generalization of results and baseline values of serum LDH and uric acid were not available for cases as it was measured after diagnosing preeclampsia.

\section{CONCLUSION}

In this study, mean serum LDH and Uric acid levels were significantly higher among cases compared to control group, their levels were higher among those with severe preeclampsia compared to non-severe preeclamsia and their increasing levels were associated with higher maternal and perinatal morbidity. So we conclude from this study that the serum LDH and Uric acid are the inexpensive and reliable markers to predict severity and maternal and foetal outcomes in patients with preeclampsia.

Funding: No funding sources Conflict of interest: None declared

Ethical approval: The study was approved by the Institutional Ethics Committee

\section{REFERENCES}

1. Von Dadleszen, Mageela P, Taylor, Muir JC, Stewart SD. Maternal hypertension and neonatal outcome among small for gestational age infants. Obstet Gynecol. 2005;106:335-9.

2. Mutlu TU, Ademoglu E. Imbalance between lipid peroxidation, antioxidant status in preeclampsia. Gynecol Obstet Invest. 1998;46:37-40.

3. Maternal mortality in 2005: estimates developed by WHO, UNICEF, VNIFPA and the World Bank, Geneva. World Health Organization, 2007. Accessed on 25 July 2020.

4. Kathleen A, Pennington, Schlitt JM, Jackson DL, Schulz LC, Schust DJ. Preeclampsia: Multiple approaches for a multifactorial disease, disease models and mechanisms. 2012;5:9-18.

5. Powe C, Levine R, Karumanchi S. Preeclampsia, a disease of the maternal endothelium:the role of angiogenic factors and implications for later cardiovascular disease. Circulation. 2011;123:285669.

6. Vasudevan D, Sreekumari S, Vaidyanathan K. Kidney fuction tests. In: Textbook of biochemistry, 6th edition. New Delhi, Jaypee Brothers, 2011;314-28.

7. Cunningham GF, Leveno KJ, Bloom SL, Spong CY, Dashe JS, Hoffman BL et al (editors). Wlliams Obstetrics. 24rd Edition. The McGraw Hill Education. 2014:1512.

8. Umasatyasri Y, Vani I, Shamita P. Role of LDH in preeclampsia-eclampsia as a prognostic marker: An observational study. IAIM. 2015;2(9):88-93.

9. Yadav BS, Jain SK, Toppo NA, Deharia C. A case control study on s.uric acid and s. creatinine levels in 
pre-eclampsia patients of a tertiary care hospital in Jabalpur district of Central India. Int J Res Med Sci. 2018;6:1519-24.

10. Sonagra DA, Dattatreya K, Murthy DSJ. Serum LDH, ALP and Uric Acid in Hypertensive Disorders of Pregnancy. International Journal of Pharmacy and Biological Sciences. 2012;2(3):201-9.

11. Gandhi M, Chavda R, Saini HB. Comparative study of serum LDH and Uric acid in hypertensive versus normotensive pregnant women. International Journal of Biomedical Research. 2015;6(01):25-8

12. Qublan H, Ammarin V, Bataineh O, Al-Shraideh Z, Tahat Y, Awamleh I et al. Lactic dehydrogenase as biochemical marker of adverse pregnancy outcome in severe preeclampsia. Med Sci Monit. 2005;11(8):CR393-7.

Cite this article as: Shivamurthy $\mathrm{G}$, Smanjunath $\mathrm{N}$. Study of estimation of serum LDH and uric acid in preeclampsia and it's clinical correlation. Int J Reprod Contracept Obstet Gynecol 2020;9:5012-8. 